\title{
Determination of the Electrical Energy Potential of Sawdust and its Products
}

\author{
Ekpo, Andifiok Aloysius \\ Department of Electrical Electronic Engineering, \\ University of Port Harcourt, Rivers State \\ Nigeria
}

\begin{abstract}
Sawdust is often used as fuel for basic domestic needs like cooking, heating etc, with the application of the right technological procedure, the chemical energy in sawdust can be converted to electrical energy. sawdust is a usually a waste from timber processing industries and can pollute the environment if not properly disposed or utilized. Electricity can be generated from sawdust directly and sawdust can be processed into other products such as sawdust briquettes, pyrolysis oil, bioethanol and producer gas which can all be used to produce electricity using either a coal based thermal plant, oil based thermal plant and gas depending on the most suitable and efficient. As the calorific value of sawdust is dependent on the moisture content of the wood and the type of wood used, hence average calorific value of sawdust was used for this research work. In this study, the heat contents of sawdust and its various products were considered as fuels for divers power plants that is most suitable accordingly. This paper uses mathematical analysis to determine the amount of electrical energy produced from sawdust and it's products. Sawdust briquettes was found to be the most efficient in terms of output power when a coal based thermal plant is utilized, the next being the utilization of a plain sawdust as fuel for a coal based thermal plant, the most optimal for the generation of electrical energy among the derivative of sawdust was pyrolysis oil being used as fuel in an oil based thermal plant.
\end{abstract}

Keywords: Sawdust briquettes, Thermal plants, Pyrolysis oil, Calorific value, moisture content

\subsection{INTRODUCTION}

Due to the increase in population, there is also great need for increase in electricity generation, improvement in the transmission and distribution of the electrical power generated. Due to global warming and other effects of $\mathrm{CO}_{2}$ emissions and the potential depletion of other fossil energy resources, renewable sources of generation of electrical power has been developed. Though some renewable methods of electricity generation are still in early stages of implementation like Tidal energy and Ocean Thermal Energy Conversion (OTEC), since ancient times biomass has been utilised for electricity generation.

There is currently high demand of electrical energy all over the globe and the utilization of fossil sources of energy poses devastating to the environment which includes the emission of Green House Gases, acid rain etc, due to this and other factors there is a need to supplement fossil sources of energy production with sources that are sustainable with little or no negative impact to the environment. [1]

The proportion of renewable energy in the global energy mix should be increased as soon as possible as this promotes sustainability and biomass is regarded as a renewable source of energy and it's regarded as a significant source of renewable energy worldwide. Making use of the energy stored in biomass to produce heat or electricity undergoes a carbon-neutral cycles as the $\mathrm{CO}_{2}$ emitted during the process of energy release is of the same proportion which was absorbed from the atmosphere by the plant for growth and other biological processes during its lifespan.

Biomass belongs to these group of renewable energy despite its emission of greenhouse gases, it has the potential to increase the cost of electrical energy, because it's among the cheapest source of electricity generation due to the fact that it is readily available and relatively cheap and can be utilized in various ways.

Biomass refers to the plant or animal materials that is used for the production of heat, energy and can also be used for the manufacture of diverse range of product after it has been processed industrially. According to [2] Biomass is produced when green plants through the process of photosynthesis utilize energy from the sun for growth and other biological processes. This green plant includes plants on land and on water bodies in the earth. The classification of a biomass resource as organic or inorganic depends on the mannerism of the storage of energy. If the sunlight energy is stored in chemical bonds, it is considered to be organic. The release of the energy stored in a chemical form occurs when bonds between carbon, oxygen and hydrogen molecules are broken either by the process of combustion, decomposition or 
digestion. It was discovered that only $1 \%$ or less of the sunlight available is stored by plant as chemical energy during the process of photosynthesis. The structural components of a biomass is the location where all the solar energy which facilitates photosynthesis are converted to chemical bonds and stored. During the process of energy utilization from biomass either through a chemical or biological process then the energy stored in form of the chemical bonds in the structure of the biomass is released in combination with oxygen, the carbon produced during the process undergoes oxidation producing $\mathrm{CO}_{2}$ and water.

Sawdust can be directly converted to heat by combustion or it can be densified through the process of palletization or briquetting.

The combustion of plant derived biomass release $\mathrm{CO} 2$, this is classified as renewable by the UN and the EU legal framework because the $\mathrm{CO} 2$ is recycled into new plants during the process of photosynthesis.

According to various researches, there are various ways of classifying biomass, the simplified method is to classify into four groups;

a) woody plant manure

b) Aquatic plant

c) Herbaceous grasses/plants

d) Woody Plants

Among this groups, herbaceous grasses/plants can be subdivided into two main groups namely: High moisture content and Low moisture content herbaceous plants. For the sake of this research, we will concentrate on saw dust and illustration and mention will be made of other woody plants biomass as well as similarities and differences will be duly stated out. Woods and wood residues possess the largest resource of biomass worldwide.

Sawdust is a very small particle of wood that falls as dust from wood when a wood work operation is carried out. Sawdust can be found in paper industries, saw mills, pulp industries and wood processing industries. They come most times in heaps of very large quantity and the method of disposal is by burning which directly lead to environmental pollution.

According to [3], Sawdust is a seen as a byproduct of wood industries and as an environmental pollutant but Sawdust is also a very important raw material utilized directly in the production of wood boards and other cheap construction material. Sawdust is also utilized in power industries as fuel processed directly or indirectly to generate electricity.

Sawdust possesses a characteristic that is similar to that of wood, this is due to the fact that they are just tiny wooden particles and it's also different owing to the fact that some of the structure of the wood have been modified [4]. In order for Sawdust to be utilized in a way similar to that of woods, it has to be modified or enhance. When using Sawdust to generate energy of any sort, consideration has to be made to it's heating value and hence there need to be a comparison between the heating value of Sawdust and that of other fuel. The bulk density of sawdust is below Sawdust $150-200 \mathrm{kgm}^{-3}$ [3]. can also be used as an insulating material used in the reduction of heat loss via conduction owing to the very low thermal conductivity of Sawdust. Sawdust can also made into briquettes which has its diverse advantages. The Density of a typical Sawdust briquette is above $100 \mathrm{kgm}^{-3}$.

Very dense sawdust briquettes can be made without a binder in a process involving high pressure and high temperature. With development in sawdust technology shows its positive use, for example, the advancement in different classes of materials including chemical such as methanol has also improved the general efficiency when utilizing sawdust. The technology involved in utilizing sawdust for energy production is still a developing one and still possesses some few unaddressed challenges. [5]

Sawdust belongs to the family of plant biomass and is further classified as a wooden biomass and sub divided to a group known as wood-waste. Among the wood-waste include, Sawdust, woodchips and wood pellets. Sawdust however as other wooden biomass can be used directly or converted using different methods and processes to obtain higher efficiency and great heat.

Irrespective of the fact that when utilizing biomass for energy generation the net emission of $\mathrm{CO}_{2}$ is zero, due to the segregation of biomass during the planting cycle, environmental impacts are inevitable. Wood constituents also includes sulfur and nitrogen, during combustion yield $\mathrm{SO}_{2}$ and $\mathrm{NO}_{\mathrm{x}}$ are emitted. Yet the emission level of these compounds is minimal in sawdust when compared with a coal-based generation [6].

When a bomb calorimeter was used, the High Heating Value (HHV) and Lower Heating Value (LHV) of sawdust was found to be $18.23 \mathrm{MJ} \mathrm{kg}^{-1}$ and $16.54 \mathrm{MJ} \mathrm{kg}^{-1}$ respectively with a moisture content of $8.25 \%$. When calculations are made for the gasification process, The Lower Heating Value is used for the calculation and not the Higher Heating Value (HHV) because the gasifier's final product is in a gaseous form [7].

\subsection{SAWDUST PRODUCTS}

\subsection{Densification Process of Briquetting}

This is a process where a compressive stress is applied to a certain volume of loosed sawdust separately or combined with other biomass materials, which causes a substantial reduction in the volume of the loosed sawdust and other constituents and therefore leading to its compression, and the products remains in a permanent compressive state. [9] 
The product obtained after densification will remain at a solid compressive state until it is utilized as fuel. Some of the technical advantages of densification includes:

1. Reduction in moisture content

2. Increase in bulk density

3. Increase in the calorific value of the product

4. Improvement in the handling and transporting capabilities

5. The burn with high flame and emits little smoke

6. The products of densification (briquettes) are easier to feed into plants.

7. The ash remnant is minimized

\subsection{Oxygen Gasification of Sawdust}

Gasification can be defined as a process of converting carboniferous materials into hydrogen, carbon monoxide, and carbon dioxide. It is done by reacting biomass or fossil fuel at a high temperature $\left(>700^{\circ} \mathrm{C}\right)$. Combustion is not occurred here and a controlled amount of oxygen sometimes with stream produces syngas or producer gas as a fuel [10].

The process of gasification of sawdust occurs in an environment where the is controlled and limited supply of oxygen or air. The composition of sawdust gas includes carbon (ii) oxide, hydrogen, methane and carbon (iv) oxide in various proportions. The process of gasification consists of a two-stage reaction which are oxidation and reduction. The oxidation and reduction occur under sub-stoichiometric conditions of air with biomass. The first section of the substoichiometric oxidation is an exothermic reaction and causes the exit of volatiles from the biomass, leading to peak temperature as much as 1400 to $1500 \mathrm{~K}$ and the production of gases like carbon (ii) oxide, carbon (iv) oxide, hydrogen as well as steam, this products are further disintegrated into carbon (ii) oxide and hydrogen by the bed of hot charcoal which is generated during the gasification process. Table 1 below shows the composition of gasification of sawdust in air neglecting water vapour
Table 1: Composition from gasification of sawdust in air.

\begin{tabular}{|l|l|}
\hline Hydrogen $\left(\mathrm{H}_{2}\right)$ & 20 \\
\hline Carbon (ii) oxide $(\mathrm{CO})$ & 25 \\
\hline Carbon(iv) oxide $\left(\mathrm{CO}_{2}\right)$ & 10 \\
\hline Methane $\left(\mathrm{CH}_{4}\right)$ & 3 \\
\hline Higher hydrocarbon & 1 \\
\hline Nitrogen & 40 \\
\hline Others & 1 \\
\hline Total & 100 \\
\hline
\end{tabular}

However, there may be some deviations, this is because the overall composition of biomass gas is to a great extent independent of the composition of the raw material but simply the mixture of gases. In some situations, if there is the presence of any Sulphur content in the raw material, hydrogen sulphide gas may be produced. The removal of hydrogen sulphide can be carried out by passing the biomass gas through water. Also, if the air supplied for the gasification process is $100 \%$ oxygen, the nitrogen content will be eliminated and the energy density will be up to 9 $\mathrm{MJ} / \mathrm{m} 3$.

\subsection{Bioethanol}

The production of ethanol can be carried out from any biological material which contains considerable amount of sugar or any substance that can be broken down or changed to sugar through any natural process examples are cellulose and starch $\mathrm{k}$. In different parts of the world ethanol are produced from different plants for example, ethanol is primarily produced from starch crops in the US mostly corn, in the EU nations from starch here barley and wheat and sugar (beet) crops are primarily used, also in the primary sources for ethanol production in China are from starch (corn and wheat) and for secondary production sugar crops like sugar canes are used [12]. Ethanol is produced through the process of fermentation. Fermentation depends on yeast which does the work of converting glucose to ethanol with carbon dioxide as its by product. Starch is also converted to sugar by the process of acid or enzyme hydrolysis. There is ready availability in commercial quantity of enzymes, organism or acid needed to convert starch to sugar and catalyze the process of glucose fermentation.

Presently, there are notable researches carried out in the area of production of ethanol from cellulose, however there is currently no known commercial production of ethanol from cellulose [12]. The main sources of cellulose feedstock are:

1. Wooden residues from wood processing/utilization industries 


\section{Agricultural residues}

3. Energy crops

4. Municipal solid waste which includes paper and materials

It has been experimentally derived between that the $30.9 \mathrm{mg}$ $\mathrm{mL}^{-1}$ to $28.43 \mathrm{mg} \mathrm{mL}^{-1}$ of ethanol can be produced from $10 \mathrm{~kg}$ of wood sawdust [13].

\subsection{Pyrolysis oil}

Pyrolysis is carried in the absence of oxygen in a large steel tub. The process is a powerful process yet simple. The process begins with the reduction of a wood into tiny pieces and the wood is quickly heated to the temperature of $450^{\circ} \mathrm{C}$ as quickly as possible. The instantaneous rise in temperature will cause the wood chips to evaporate in seconds and the wood vapour is capture and cooled to room temperature, this causes the condensation of the wood vapour which becomes liquid. Other by product also occur as a result of this thermal processing this are char and gas. The liquid obtained is very efficient as a kilogram of wood can produce up 700 grams of pyrolysis oil [14].

BTG-BTL's oil also called pyrolysis oil can be produced by almost any kind of cellulosic material. The oil consist of small portions of ash and the energy density is greatly increase to up to $400 \%$ compared with the original (parent) biomass material. Pyrolysis oil has a characteristic pungent odour and it has reddish brown appearance. Pyrolysis oil contains other functional groups like ketones, carbohydrates, furans, pyrans, hydrocarbons etc. Pyrolysis oil has a density of approximately $1170 \mathrm{~kg} / \mathrm{m}^{3}$, which makes it denser than any other known fuel oil and also denser than the parent biomass that it was derived from. Pyrolysis oil has the propensity to undergo degradation if not properly handled. The $\mathrm{pH}$ value of about 3 , and the HHV of the oil ranges from $16 \mathrm{MJ} / 1$ to $23 \mathrm{MJ} / 1[15]$.

The oil does not easily fuse as a mixture with hydrocarbons because it is polar in nature and it contains a huge number of oxygenated components. Pyrolysis oil can be applied in the generation of electricity either in a large scale or a much smaller scale. These systems are found in power industries and large companies in other to meet the demand for electricity [15].

The aim of this study is to find out the magnitude of electrical energy that can be derived from $1 \mathrm{~kg}$ of sawdust.

\subsection{METHODOLOGY}

Sawdust and its direct derivatives will be considered separately and its heating value, will be derived and utilized using a thermal power plant to generate the energy and this will be demonstrated mathematically.

The heating value, will be derived and utilized using a thermal power plant to generate the energy and this will be demonstrated mathematically.

The plant that will be utilized will be a coal-based thermal power plant whose efficiency is between $35-38 \%$ will be utilized for generation using regular (plain) sawdust and sawdust briquettes.

The oil-based thermal plant with overall efficiency of 42$46 \% \%$ will be utilized for the generation using cellulosic ethanol produced derived from sawdust.

A gas-based thermal plant with overall efficiency of $35-42 \%$ will be utilized for the generation of electrical power using hydrogen produced from the gasification of sawdust.

Our analysis will be done based on Higher Heating Value (HHV) and the Lower Heating Value (LHV) and using a steam engine ant each of the samples as a fuel to the steam generator.

Density of sawdust $=210 \mathrm{Kg} / \mathrm{m}^{3}$

Table 2: Calorific value of sawdust and its products (derivatives)

\begin{tabular}{|l|l|l|}
\hline $\begin{array}{l}\text { Sawdust and } \\
\text { Products }\end{array}$ & $\begin{array}{l}\text { Lower Heating } \\
\text { Values (LHV) } \\
\text { MJ/Kg }\end{array}$ & $\begin{array}{l}\text { Higher Heating } \\
\text { Values (HHV) } \\
\text { MJ/Kg }\end{array}$ \\
\hline Plain Sawdust & 16.54 & 18.23 \\
\hline $\begin{array}{l}\text { Sawdust } \\
\text { Briquettes }\end{array}$ & 35.6 & 38.98 \\
\hline Bioethanol & 21.2 & 26.4 \\
\hline Pyrolysis Oil & 13.68 & 19.66 \\
\hline $\begin{array}{l}\text { Producer } \\
\text { (wood) Gas }\end{array}$ & 4.2 & 5.4 \\
\hline
\end{tabular}




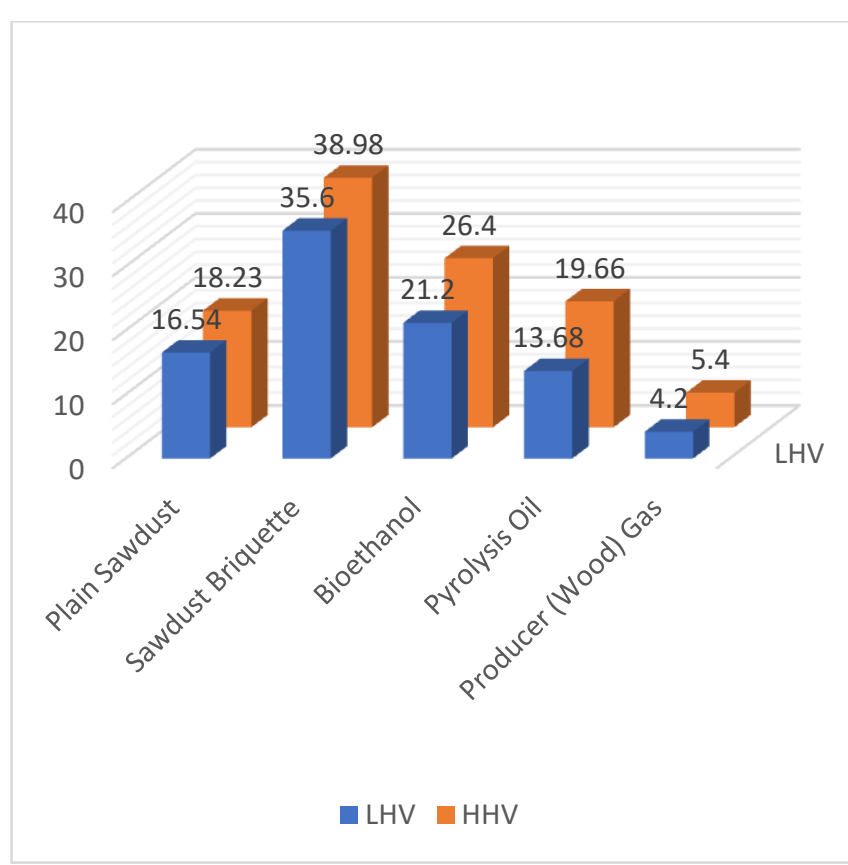

Fig. 1: Calorific Values of Sawdust and its products

Table 3: Sawdust/products and its corresponding power plants used with their efficiencies respectively

\begin{tabular}{|l|l|l|}
\hline $\begin{array}{l}\text { Sawdust and } \\
\text { Products }\end{array}$ & Power plants utilized & $\begin{array}{l}\text { Overall } \\
\text { efficiencies } \\
\text { of power } \\
\text { plants }\end{array}$ \\
\hline Plain Sawdust & $\begin{array}{l}\text { Coal based thermal } \\
\text { power plants }\end{array}$ & $42 \%$ \\
\hline $\begin{array}{l}\text { Sawdust } \\
\text { Briquettes }\end{array}$ & $\begin{array}{l}\text { Oil based thermal power } \\
\text { plants }\end{array}$ & $45 \%$ \\
\hline Bioethanol & $\begin{array}{l}\text { Gas based thermal } \\
\text { Power plants }\end{array}$ & $52 \%$ \\
\hline Pyrolysis oil & $\begin{array}{l}\text { Combined cycle gas } \\
\text { Turbine plants }\end{array}$ & $62 \%$ \\
\hline Gaducer (wood) & &
\end{tabular}

\subsection{Analysis}

Energy $(\mathrm{J})=$ Power $(\mathrm{w}) \times$ time $(\mathrm{s})$

One watt $=1$ Joules per second

One watt second $=1$ Joules

$3.6 \mathrm{MJ}=1 \mathrm{Kwh}$

$1 \mathrm{MJ}=1 /(3.6) \mathrm{Kwh}$

$1 \mathrm{MJ}=0.2778 \mathrm{Kwh}$

Energy leaving each plant $=$ Energy Input (Heating Values) $\times$ Overall efficiency of individual power plants

\subsection{Energy leaving the Power Plant}

\subsubsection{Plain Sawdust}

A plain sawdust undergoing direct combustion in a coal based thermal power plant of efficiency of $42 \%$ will yield:

$\mathrm{LHV}=16.54 \mathrm{MJ} / \mathrm{Kg} \times 0.42=6.95 \mathrm{MJ} / \mathrm{Kg}$

$\mathrm{HHV}=18.23 \mathrm{MJ} / \mathrm{Kg} \times 0.42=7.66 \mathrm{MJ} / \mathrm{Kg}$

$1 \mathrm{Kg}$ of Plain sawdust will yield:

$6.95 \times 0.2778 \mathrm{Kwh}=1.93 \mathrm{Kwh}$
$18.23 \times 0.2778 \mathrm{Kwh}=2.13 \mathrm{Kwh}$

\subsubsection{Sawdust Briquette}

Sawdust Briquette undergoing a direct combustion and utilized in a coal based thermal plant of efficiency of $42 \%$ will yield:

$\mathrm{LHV}=35.6 \mathrm{MJ} / \mathrm{kg} \times 0.42=14.95 \mathrm{MJ} / \mathrm{Kg}$

$\mathrm{HHV}=38.98 \mathrm{MJ} / \mathrm{Kg} \times 0.42=16.37 \mathrm{MJ} / \mathrm{kg}$

$1 \mathrm{Kg}$ of Sawdust briquette

$14.95 \times 0.2778 \mathrm{Kwh}=4.15 \mathrm{Kwh}$

$16.37 \times 0.2778 \mathrm{Kwh}=4.55 \mathrm{Kwh}$

\subsubsection{Bioethanol}

Bioethanol from sawdust undergoing combustion in an oil based thermal plant of efficiency of $45 \%$ will yield:

$1 \mathrm{~kg}$ of sawdust will yield 250 grams of bioethanol

$\mathrm{LHV}=26.4 \mathrm{MJ} / \mathrm{Kg} \times 0.45 \times 0.25=2.77 \mathrm{MJ} / \mathrm{Kg}$

$\mathrm{HHV}=30.2 \mathrm{MJ} / \mathrm{Kg} \times 0.45 \times 0.25=3.4 \mathrm{MJ} / \mathrm{Kg}$

$1 \mathrm{Kg}$ of Bioethanol produced from sawdust will yield:

$2.77 \times 0.2778 \mathrm{Kwh}=0.77 \mathrm{Kwh}$

$3.4 \times 0.2778 \mathrm{Kwh}=0.94 \mathrm{Kwh}$

\subsubsection{Pyrolysis oil}

$\mathrm{LHV}=16 \mathrm{MJ} / 1$

$\mathrm{HHV}=23 \mathrm{MJ} / \mathrm{l}$

Density of pyrolysis oil $=1.17 \mathrm{Kg} / 1$

$\mathrm{LHV}=16 /(1.17)=13.68 \mathrm{MJ} / \mathrm{Kg}$

$\mathrm{HHV}=23 /(1.17)=19.66 \mathrm{MJ} / \mathrm{Kg}$

Pyrolysis oil being used as fuel in an oil-based plant with efficiency of $45 \%$ will yield:

$\mathrm{LHV}=13.68 \mathrm{MJ} / \mathrm{Kg} \times 0.45=6.16 \mathrm{MJ} / \mathrm{Kg}$

$\mathrm{HHV}=19.66 \mathrm{MJ} / \mathrm{Kg} \times 0.45=8.85 \mathrm{MJ} / \mathrm{Kg}$

But $1 \mathrm{~kg}$ of Sawdust will yield 700 grams of Pyrolysis oil,

$\mathrm{LHV}=6.16 \times 70 \%=4.31 \mathrm{MJ} / \mathrm{Kg}$

$\mathrm{HHV}=19.66 \times 70 \%=6.19 \mathrm{MJ} / \mathrm{Kg}$

$1 \mathrm{~kg}$ of pyrolysis oil will produced from sawdust will yield:

$4.31 \times 0.2778 \mathrm{Kwh}=1.19 \mathrm{Kwh}$

$6.19 \times 0.2778 \mathrm{Kwh}=1.72 \mathrm{Kwh}$

\subsubsection{Producer (wood) Gas}

Density of Producer gas $=0.95 \mathrm{Kg} / \mathrm{m} 3$

$1 \mathrm{Kg}$ of sawdust yields $1.5 \mathrm{~m} 3$ of producer gas

$1 \mathrm{Kg}$ of sawdust produces $=0.95 \mathrm{Kg} / \mathrm{m} 3 \times 1.5 \mathrm{~m} 3=1.425 \mathrm{Kg}$

$1 \mathrm{Kg}$ of sawdust yields $=1.425 \mathrm{Kg}$ of producer gas

The LHV and HHV for producer gas for $1 \mathrm{~kg}$ of sawdust is given as:

$\mathrm{LHV}=1.425 \times 4.2 \mathrm{MJ} / \mathrm{Kg}=5.985 \mathrm{MJ} / \mathrm{Kg}$

$\mathrm{HHV}=1.425 \times 5.4 \mathrm{MJ} / \mathrm{Kg}=7.695 \mathrm{MJ} / \mathrm{Kg}$

3.2.5.1 Gas based thermal power plant with the efficiency of 52\% Energy leaving the plant is given by:

$5.985 \mathrm{MJ} / \mathrm{Kg} \times 0.52=3.112 \mathrm{MJ} / \mathrm{Kg}$

$7.695 \mathrm{MJ} / \mathrm{Kg} \times 0.52=4.00 \mathrm{MJ} / \mathrm{Kg}$

$1 \mathrm{Kg}$ of sawdust converted to producer gas will yield:

$3.112 \times 0.2778 \mathrm{Kwh}=0.86 \mathrm{Kwh}$

$4.00 \times 0.2778 \mathrm{Kwh}=1.1 \mathrm{Kwh}$

3.2.5.2 Combined cycle gas power plant with efficiency of $62 \%$ Energy leaving the plant:

$5.985 \mathrm{MJ} / \mathrm{Kg} \times 0.62=3.71 \mathrm{MJ} / \mathrm{Kg}$

$7.695 \mathrm{MJ} / \mathrm{Kg} \times 0.62=4.77 \mathrm{MJ} / \mathrm{Kg}$

$1 \mathrm{Kg}$ of sawdust converted to producer gas to run a combined cycle power plant will yield: 
$3.71 \times 0.2778 \mathrm{Kwh}=1.03 \mathrm{Kwh}$

$4.77 \times 0.2778 \mathrm{Kwh}=1.33 \mathrm{Kwh}$

\subsection{DISCUSSION}

From the Table 4.1 below, it is clearly seen that the electrical energy potential ranges from $0.77 \mathrm{Kwh}$ to $4.55 \mathrm{Kwh}$ per kilogram of sawdust. The difference owing to losses during the process of conversion to various products (derivatives) and the method of generation.

Sawdust briquette has the highest energy electrical energy potential with $4.55 \mathrm{Kwh}$ of energy per kilogram of sawdust while the least is bioethanol with least energy potential of $0.77 \mathrm{Kwh}$ of energy derived from a kilogram of sawdust. However, despite the reduced energy potential of other derivatives (products) of sawdust like bioethanol, pyrolysis oil, producer (wood gas) they have several advantages like effective transportation and application in multiple systems.

Therefore, for electricity generation the use of sawdust briquette in a coal based thermal plant is the most optimal way of generating electricity when cost is considered but might not be optimum when carbon emissions and versatility is being used as the yardstick.

Table 4: Maximum and minimum power potential of sawdust and its products (derivatives)

\begin{tabular}{|l|l|l|}
\hline $\begin{array}{l}\text { Sawdust and } \\
\text { Products }\end{array}$ & $\begin{array}{l}\text { Minimum } \\
\text { Possible Power } \\
\text { Output (Kwh) }\end{array}$ & $\begin{array}{l}\text { Maximum } \\
\text { Possible Power } \\
\text { Output(Kwh) }\end{array}$ \\
\hline Plain Sawdust & 1.93 & 2.13 \\
\hline $\begin{array}{l}\text { Sawdust } \\
\text { Briquettes }\end{array}$ & 4.15 & 4.55 \\
\hline $\begin{array}{l}\text { Bioethanol } \\
\text { Pyrolysis oil }\end{array}$ & 0.77 & 0.94 \\
\hline $\begin{array}{l}\text { Producer } \\
\text { (wood) Gas } \\
\text { (Gas Thermal } \\
\text { plants) }\end{array}$ & 0.86 & 1.72 \\
\hline $\begin{array}{l}\text { Producer } \\
\text { (Wood) Gas } \\
\text { using CCGP }\end{array}$ & 1.03 & 1.33 \\
\hline
\end{tabular}

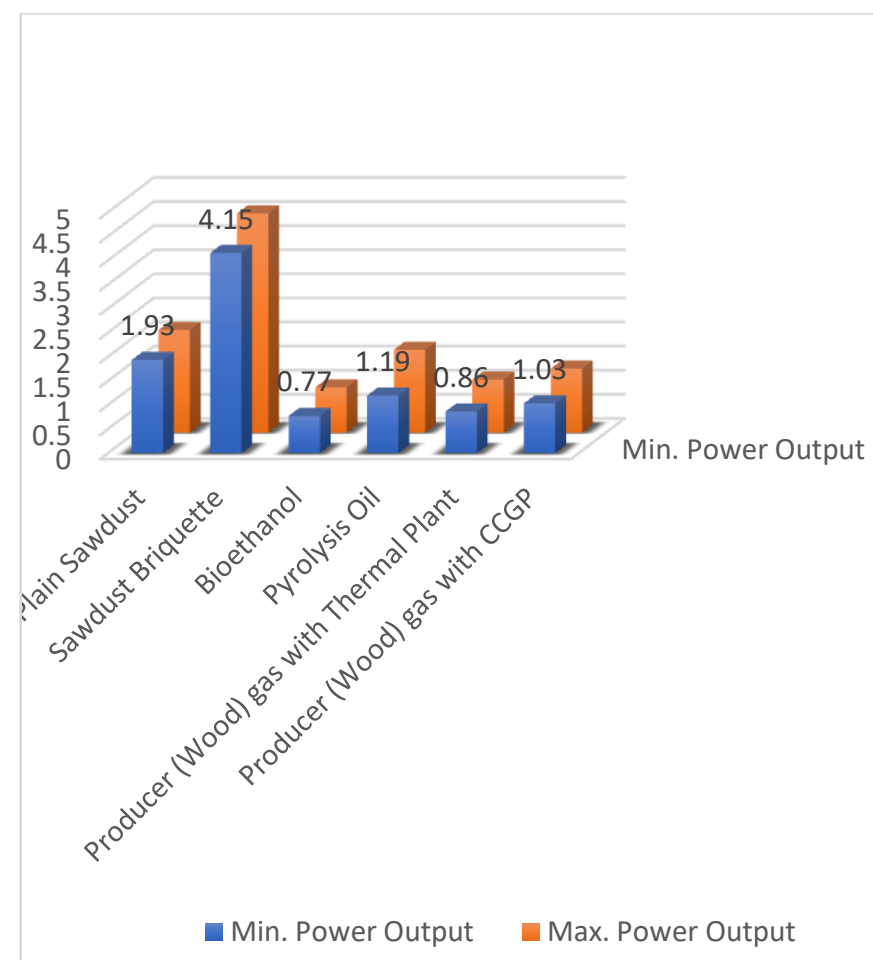

Fig. 2: A graph of maximum electrical energy output of sawdust and various sawdust materials

\subsection{CONCLUSION AND RECOMMENDATION}

The world energy mix is incomplete with the energy derived from biomass. Sawdust/wood waste is one of the main constituents for the generation of energy from biomass. Sawdust has many products (derivatives) whose electrical energy potential in terms of electrical energy in Kwh and heat content in Joules varies.

The energy potential of sawdust is seen to be dependent highly on the LHV and HHV of the product/derivative and also dependent on the efficiency of the process used in the conversion from the chemical form of energy into electrical energy. The energy content of the sawdust and its derivatives differs based on the type of wood(trees) and the moisture content. In this work, the nature and type of wood is not considered as the average energy content of wood is utilized. In this research the electrical energy potential of sawdust briquette is the highest when burnt as fuel in a coal based thermal, the second best is that of plain sawdust and the least in this category is the bioethanol owing to reduced efficiency in the conversion process.

The integration of biomass in the energy mix of every society is very beneficial as it is proven to be a carbon reduction technology and also cost effective. 


\subsection{REFERENCES}

[1] Mirko Barz (2008). Biomass Technology for Electricity Generation in community.

[2] McKendry, Peter. (2002). Energy Production from biomass. Bioresource technology. 83, 37-46.

[3] Rominiyi, O.L., Adaramola, B.A., Ikumapayi, O.M., Oginni, O.T. and Akinola, S.A. (2017) Potential Utilization of Sawdust in Energy, Manufacturing and Agricultural Industry; Waste to Wealth. World Journal of Engineering and Technology, 5, 526-539.

[4] Fischer, J (2003). Technologies for small scale Biomass CHP-plants - an actual survey; Riso International Energy Conference, Riso, Denmark.

[5] Mafakheri, F.; Nasiri, F. (2014). "Modeling of biomass-to-energy supply chain operations: Applications, challenges and research directions". $\begin{array}{llll}\text { Energy } & \text { Policy } & \end{array}$ doi:10.1016/j.enpol.2013.11.071

[6] Zia Hag (2013), Biomass for Electricity Generation.

[7] Miskam, Z.A. Zainal and I.M. Yusof, (2009). Characterization of Sawdust Residues for Cyclone Gasifier. Journal of Applied Sciences, 9: 2294-2300

[8] Kellett, P. (1999). Combined Heat and Power for the Irish Wood Processing Industry - Report on Wood Biomass, Irish Energy Center - Renewable Energy Informatin Office, Bandon, Ireland.

[9] Adegoke, C.O. (2003) Available Alternative Energy Source for Domestic Use: A Case Study of Solar Cookers, Dryers and Sawdust Briquettes. Paper Work. Agric Eng Int: CIGR Journal, 15(3): 136-140.

[10] Imrul Reza Shishir, Abul Kalam Azad and Tanjim Ahmed (2014). Electricity Generation Based On Biomass Residue: Scope, Relevance and Applications.

[11] Gunjuan, D. and Gaurab, B. (2013) Using Biomass as Fuel Substitute to Reduce Fuel Cost in Locomotive. ISSN : 2319 - 3182, Volume-2, Issue-3, 2013.

[12] IEA 2004. Biofuels for transport: an international perspective. Interview by International Energy Agency, Confidential Industry Source: www.cti2000.it/Bionett/All-2004-004\% 20IEA\%20biofuels\%20report.pdf. (Accessed May 13, 2006).
[13] Nwakaire J. N., S. L. Ezeoha, and B. O. Ugwuishiwu. 2013. Production of cellulosic ethanol from wood sawdust.

[14] Elwin Gansekoele (2019) https://www.btgbtl.com/en/applications/oilproperties

[15] Alison Ballance (2018) https://www.rnz.co.nz/national/programmes/ourchangi ngworld/audio/2018653988/biofuels-made-fromsawdust

[16] LHV and HHV of biofuel. (2019, September 14). Retrieved from http://www.eubia.org/wikibiomass/biofuel

[17] N.R.Banapurmath, V.S Yaliwal, S.Y.Adaganti and S.S. Halewadimath (2018) Energy from Toxic Organic waste for Heat and Power Generation. 